ROCZNIKI TEOLOGICZNE

Volume LXV, issue 9 - 2018

Englis h version

DOI: http://dx.doi.org/10.18290/rt.2018.65.9-2en

REV. KRZYSZTOF KAUCHA

\title{
THE LUBLIN SCHOOL OF FUNDAMENTAL THEOLOGY AND ITS ACHIEVEMENTS
}

\begin{abstract}
Fundamental theology as a discipline and academic center conducting research as well as didactic and organizational activity has existed at the John Paul II Catholic University of Lublin since its beginning, first as the Department of Fundamental Theology (1918-20), then the Section of Fundamental Theology (1920-99), and since 1999 as the Institute of Fundamental Theology. As it developed, the center began to take the form of a scientific school, the Lublin School of Fundamental Theology. Its foundations were laid by Rev. Edward Kopeć. Subsequently, it was developed by, among others, Rev. Stanisław Nagy, Rev. Romuald Łukaszyk, Rev. Henryk Zimoń (religious scholar), and especially by Rev. Marian Rusecki (a student of Rev. E. Kopeć), the main co-founder of the school and its most prolific author, whose scientific achievements are the department's showcase and have influenced contemporary Polish fundamental theology. During his time, especially at the beginning of the $21^{\text {st }}$ century, the school reported its greatest scientific and organizational achievements. Currently, it is continually being developed by Rev. M. Rusecki's students who work at the Institute of Fundamental Theology and its graduates working in other centers. This article presents the scientific characteristics (historical outline, features and main trends) of the Lublin School of Fundamental Theology (Section 1) and its most important achievements (Section 2): the main publications, organizational achievements as well as national and international cooperation.
\end{abstract}

Key words: Apologetics; Ethnology of Religion; Fundamental Christology; Fundamental Ecclesiology; Fundamental Theology; History of Religions; Lexicon of Fundamental Theology (in Polish); Lublin School of Fundamental Theology; Religiology; Second International Congress of Fundamental Theology "Christianity of Tomorrow"; Theology of Religion.

Rev. Krzysztof KaUcha, KUL Prof. at the Chair of Fundamental Christology and Ecclesiology at CUL; mailing address: ul. Nałęczowska 94, 20-831 Lublin; e-mail: kkaucha@kul.pl 


\section{THE LUBLIN SCHOOL OF FUNDAMENTAL THEOLOGY 1.1. A HISTORICAL OUTLINE*}

Fundamental theology at KUL has undergone many substantive changes similar to those at the Western European centers of Catholic theology. The Second Vatican Council was most influential in opening the Church to the contemporary world, a spirit of dialogue, a departure from traditional intellectualist apologetics, taking into consideration contemporary trends in philosophical and humanistic thought, and deepening in the light of faith our understanding of Christian Revelation and theology. The Lublin Center is distinguished by the fact that in its development, starting in the mid-1970s, it assumed the form of an academic research center called the Lublin School of Fundamental Theology. In contrast to the centers in the West, for many decades it functioned in a country ruled by a communist dictatorship dependent on the Soviet Union and in a university which was the only center of free scientific thought in the communist bloc nations.

The preparatory period for the establishment of the Lublin School of Fundamental Theology began in 1956 and, for about 20 years, it was associated with the research activity of Rev. Edward Kopeć, who can be considered the school's pioneer. He was the first person in Poland who began to cultivate modern fundamental theology derived from apologetics, but based on other methodological foundations. Shortly after starting work at KUL (1956), he gradually began introducing personalistic elements into apologetics (especially in understanding God's Revelation, faith and miracle) following Western authors (J. Mouroux, K. Adam, R. Guardini, A. Brunner, C. Cirne-Lima, W. Bulst, E. Masure, A. Liégé, R. Latourelle, R. Aubert, L. Monden and J. Guitton), but eliminating the polemical spirit from traditional apologetics. Over time, he strongly opted for fundamental theology, methodologically distinguishing it from traditional apologetics, and began to create a system of personalistic fundamental theology, although it was limited to the socalled Christological fact. ${ }^{1}$

\footnotetext{
* Krzysztof KAUCHA, "Wiarygodność i wiara w ujęciu lubelskiej szkoły teologii fundamentalnej" [Credibility and Faith according to Lublin School of Fundamental Theology], in Wiarawiarygodność [Faith-Credibility], ed. Damian Wąsek (Kraków: Wydawnictwo Naukowe UPJPII w Krakowie, 2014), 49-85.

${ }^{1}$ Marian RUSECKI, "Elementy personalistycznej teologii fundamentalnej w ujęciu Edwarda Kopcia" [Elements of Personalistic Fundamental Theology according to Edward Kopeć], Roczniki Teologiczno-Kanoniczne 32, no 2 (1985): 23-37.
} 
In 1956, Rev. Czesław Stanisław Bartnik (born 1929) was employed at KUL, who in the same year defended his doctoral dissertation in the field of fundamental theology written under the direction of Rev. Bolesław Radomski. He completed his postdoctoral thesis in 1965 in the field of fundamental theology and the history of theology. In 1958, Rev. Stanisław Nagy started his academic research work at KUL, completing his theology licentiate and defending his $\mathrm{PhD}$ at the Catholic University of Lublin in 1954. He took up the so-called ecclesiological fact. Thanks to these researchers, the Section of Fundamental Theology of the Catholic University of Lublin was created in 1958 and became the first academic center in Poland to cultivate fundamental theology, more methodologically and substantively distinct from traditional apologetics and the so-called Warsaw School of Apologetics founded by Rev. Wincenty Kwiatkowski.

The origins of the Lublin school can be dated to 1974-76. In 1976, Rev. Kopeć for the first time entitled his script for students as Fundamental Theology, ${ }^{2}$ although several of his previous editions appeared under the title Apologetics. In 1974, Rev. Marian Rusecki received his doctoral degree (based on the dissertation Contemporary Discussions on the Theory of Apologetics written under the direction of Rev. Kopeć), and was employed at KUL that year. His doctoral dissertation influenced the methodology of fundamental theology in the Lublin center and beyond. ${ }^{3}$ The importance of the center increased thanks to its employees obtaining subsequent academic degrees and titles, the increase in academic research achievements, the development of thought and its employees completing important functions in the world of science on a national scale. Rev. Henryk Seweryniak, who worked at KUL for several years, where he habilitated, ${ }^{4}$ moved to Warsaw in 1994 , where at ATK (later UKSW) he initiated the transformation of the Warsaw School of Apologetics into modern fundamental theology (the University Senate formally changed the name of the Apologetics Section to the Fundamental Theology Section in 1995). ${ }^{5}$

\footnotetext{
${ }^{2}$ Edward Kopeć, Teologia fundamentalna [Fundamental Theology] (Lublin: RW KUL, 1976³).

${ }^{3}$ Marian RUSECKI, "Wiarygodność chrześcijaństwa" [Credibility of Christianity], vol. 1: Z teorii teologii fundamentalnej [From Theory of Fundamental Theology], (Lublin: TN KUL, 1994). Nigdy nie ukazały się kolejne tomy, jednak można za nie uznać późniejsze traktaty naukowe opublikowane przez Rev. Ruseckiego.

${ }^{4}$ Henryk Seweryniak, Antropologia i teologia fundamentalna. Studium antropologii teologicznofundamentalnej Wolfharta Pannenberga [Anthropology and Fundamental Theology. A Study of Fundamentaltheological Anthropology by Wolfhart Pannenberg], (Płock, 1993).

${ }^{5}$ Marek SKIERKOWSKI, "Wiara i/a wiarygodność w ujęciu ośrodka warszawskiego" [Faith and Credibility according to Catholic academics in Warsaw], in: Wiara-wiarygodność, 87-102.
} 
We can say that the early 1990s was the beginning of the self-awareness of the school's start. First, Rev. Nagy, ${ }^{6}$ then Rev. Rusecki ${ }^{7}$ and finally Rev. Kaucha ${ }^{8}$ wrote about it. The number of its students and graduates increased (till today, doctorate degrees in theology in the field of fundamental theology were obtained by about 100 people). A few of them were employed as research and teaching staff at KUL, and many others in academic centers throughout Poland (including Rev. Andrzej Nowicki, Rev. Tadeusz Dola, Rev. Jan Perszon, Eugeniusz Sakowicz, Rev. Andrzej Anderwald, Rev. Wojciech Szukalski, Rev. Marek Żmudziński, Rev. Roman Słupek, Rev. Daniel Swend, Rev. Paweł Rabczyński, Rev. Grzegorz Dziewulski, Rev. Zbigniew Chromy, Rev. Rafał Pokrywiński). The school's great development is reflected in numerous research publications by Rev. Rusecki (who is the most important co-founder and architect of the school), including work under his supervision not only in the field of fundamental theology but also in religious studies and theology of religion. The school's achievements were also publications by pupils and co-workers of Rev. Rusecki, especially their doctoral and postdoctoral dissertations. At the initiative of Rev. Rusecki, the school was distinguished by its achievements on a national and international scale, which will be discussed in the next section of this article. For his entire research work, Rev. Rusecki received an honorary doctorate (honoris causa) from the Pontifical Faculty of Theology in Wrocław (April 16, 2012).

For a long time, the Department of History and Ethnology of Religions at the Center for Fundamental Theology at KUL conducted scientific and didactic activities independently due to methodological reasons, which were complementary in relation to fundamental theology. ${ }^{9}$ Initially, its didactic activity was limited to conducting lectures for students of fundamental theology. Full didactic and scientific activity began in 1958, when it was reactivated as

\footnotetext{
${ }^{6}$ Stanisław NAGY, "Sekcja Teologii Fundamentalnej" [Section of Fundamental Theology], in: Księga pamiątkowa w 75-lecie Katolickiego Uniwersytetu Lubelskiego. Wkład w kulturę polska w latach 1968-1993 [75 Years of Catholic University of Lublin Jubilee Book. Contribution to Polish Culture in the Period of 1968-1993], ed. Marian Rusecki (Lublin: RW KUL, 1994), 188-197.

${ }^{7}$ Marian RUSECKI, “Tło i okoliczności powstania deklaracji Dominus Iesus” [Background and Circumstances of the Declaration Dominus Iesus], in Wokót deklaracji „Dominus Iesus” [About the Declaration Dominus Iesus], ed. Marian Rusecki (Lublin: TN KUL, 2001), 43.

${ }^{8}$ KAUCHA, "Wiarygodność i wiara w ujęciu lubelskiej szkoły teologii fundamentalnej."

${ }^{9}$ Henryk ZıMoń, "W trzydziestolecie reaktywowania Katedry Historii i Etnologii Religii Katolickiego Uniwersytetu Lubelskiego" [In Occasion of the $30^{\text {th }}$ Anniversary of Reactivation of the Chair of History and Ethnology of Religion at Catholic University of Lublin], in Z badań nad religia i religijnościa ludowa [Out of Researches of Religion and Folk Religion], ed. Henryk Zimoń (Warszawa: Verbinum, 1988), 149-158.
} 
the Department of History and Ethnology of Religion and entrusted to Rev. T. Chodzidło, ethnologist and religious scholar, a student of Rev. Wilhelm Schmidt. The development of the chair was made possible thanks to Rev. Henryk Zimoń, who started working at KUL in 1973, and in 1985 became the head of the Department. He conducted monographic lectures in the field of religion of primitive peoples, rituals and beliefs of African peoples as well as Buddhism. By the resolution of the Faculty Council on October 15, 1985, the department of "religious studies" was established within the chair, which allowed students to undertake full-time studies on various religiological disciplines, with particular emphasis on humanistic religious studies. After Rev. Zimon's retirement (October 1, 2012) the head of the chair became Rev. Zdzisław Kupisiński.

\subsection{THE SCHOOL'S FEATURES AND MAIN RESEARCH TRENDS}

The main features of the Lublin School of Fundamental Theology are: a compact methodology developed in the form of the theory of fundamental theology by Rev. Kopeć and mainly Rev. Rusecki, combining traditional treatises (so-called demonstrationes: religiosa, christiana and catholica) as part of a single concept of fundamental theology and its subject matter, exposing the credibility and veryfiying (not proving) Christian Revelation as the goal of fundamental theology, Christocentrism (by presenting the fullness of Revelation and salvation in Jesus Christ), personalism (through the development of a personalist concept of fundamental theology, Divine Revelation, the Church, miracles, and above all faith), the revelatory theory of the genesis of religion, an apologetic dimension evident in the deepening of traditional arguments that make Christianity credible (scriptural and especially resurrectionist and miraculistic) and innovative (e.g., prescriptive, bonative, calonistic, agapetological, martyrological, hopeful, culture-forming, personalistic, praxeological, on sanctity, axiological, comparistive), openness to contemporary cultural and multi-religious contexts, diagnosis of problems, and the credibility and identity of the Church in the modern world.

Initially, the main research trend for Rev. Kopeć was the Christological fact, and more specifically, the fact of the historicity of Jesus Christ, the concept of God's Revelation, faith, miracles and the resurrection of Jesus Christ. Rev. Nagy dealt with both the ecclesiological fact (apologetic or fundamental ecclesiology) conducting research on the primary formation of Church structures 
(the primacy of the bishop of Rome, the apostles and their succession, formation of the Church hierarchy), the Church's features, ecumenism, and finally the person and teachings of John Paul II. Rev. Rusecki began his research with the methodology of fundamental theology, then he made detailed studies on the theology of miracles (in a historical and contemporary perspective, devoting his habilitation on the motivational function of miracles in twentieth century theology), ${ }^{10}$ religiology (as a holistic interpretation of the fact and credibility of religion withing relisious studies, philosophy and theology of religion), theology of Revelation, the resurrection of Jesus Christ, he worked on traditional arguments for the credibility of Christian Revelation, and also created new ones. He consciously connected previously separated Christological, ecclesiological and religious facts (demonstratio religiosa), striving to develop a coherent scientific system.

Initiated by Rev. Łukaszyk and Rev. Rusecki, the theology of religion was developed by Fr. Ireneusz Ledwon and focuses on the unique character of Christianity and the theological value of non-Christian Religions. ${ }^{11} \mathrm{Re}-$ search on the problems of faith, the staurological-resurrectional credibility of Christianity and some new arguments is carried out by Rev. Jacenty Mastej. ${ }^{12}$ Rev. Krzysztof Kaucha first dealt with elaborating an agapetological argument and other arguments, and over time focused on achieving the goal of fundamental ecclesiology by extracting from the teachings of John Paul II argumentative methods for the credibility of the Church. ${ }^{13}$ Rev. Andrzej Pietrzak took on the so-called option for the poor as a sign of the Church's credibility, Latin American theology, missionary models and the missions, and the issue of inculturation of the Christian faith. ${ }^{14}$ In the religious studies

\footnotetext{
${ }^{10}$ Edited: Wierzcie moim dziełom. Funkcja motywacyjna cudu w teologii XX wieku [Believe in My Work. Motivational Function of Miracle in Theology of the XX ${ }^{\text {th }}$ Century], (Katowice: Księgarnia św. Jacka, 1988).

${ }^{11}$ Postdoctoral dissertation „... i nie ma $w$ żadnym innym zbawienia”. Wyjątkowy charakter chrześcijaństwa $w$ teologii posoborowej $[, \ldots$ and there is no salvation in any other name”. Particular Character of Christianity in Post-conciliar Theology] (Lublin: Wydawnictwo KUL, $2006^{1}, 2012^{2}$ ).

${ }^{12}$ Postdoctoral dissertation Staurologiczno-rezurekcyjna wiarygodność chrześcijaństwa [Staurological-Resurrectional Credibility of Christianity] (Lublin: Wydawnictwo KUL, 2009¹ $2014^{2}$ ).

${ }^{13}$ Postdoctoral dissertation Wiarygodność Kościoła w kontekście wyzwań wspótczesności europejskiej w świetle nauczania Jana Pawta II [Credibility of the Church in the Context of Contemporary European Challenges in the Light of John Paul II's Teaching] (Lublin: Wydawnictwo KUL, 2008).

${ }^{14}$ Postdoctoral dissertation Modele ewangelizacji kultur $i$ inkulturacji wiary $w$ teologii latynoamerykańskiej [Models of Evangelization of Cultures and of Inculturation of Faith in LatinAmerican Theology) (Lublin: Wydawnictwo KUL, 2013).
} 
branch, research was conducted on the Religions of primitive peoples, rituals and beliefs of some African peoples, the hypothesis of the original monotheism by W. Schmidt and Buddhism (Rev. Zimoń). Rev. Kupisiński examines folk religiosity, Polish customs and folk rituals, folk thanatology, ${ }^{15}$ the Religion of the Slavs and so-called new religious movements.

Currently, the main directions of academic research in the Chair of Fundamental Christology and Ecclesiology are: methodology and history of fundamental theology, justifying the revealed nature of Christianity, justifying the credibility of the Person of Jesus Christ and the Church, new arguments for the credibility of Christianity and the Church, theology of Divine Revelation, theology of miracles, theology of faith, the resurrection of Jesus Christ, permanent ecclesiogenesis, the identity of the Church and the identity of the Catholic Church in Poland. The main directions of research at the Chair of Religiology and Missiology are: rituals and folk religiosity (annual rituals, rites of passage: birth, wedding, funeral, folk thanatology), Slavic Religion, so-called new religious movements, the methodological status of theology of Religion, the concept and genesis of Religion in the theological perspective, theological basis of interreligious dialogue, Christianity in Relation to other religions, theological foundations and justification of the missionary activity of the Church, Latin American theology, Christianity and cyberculture, the problems of poverty and exclusion and the credibility of Christianity. Both chairs conduct research together on the history and achievements of the center of fundamental theology at the Catholic University of Lublin.

\section{IMPORTANT ACHIEVEMENTS OF THE LUBLIN SCHOOL OF FUNDAMENTAL THEOLOGY}

\subsection{SIGNIFICANT PUBLICATIONS}

First of all, the Lexicon of Fundamental Theology ${ }^{16}$ should be mentioned, which is the first of its kind in Poland and the third or fourth lexicon in the

\footnotetext{
${ }^{15}$ Postdoctoral dissertation Śmierć jako wydarzenie eschatyczne. Zwyczaje, obrzędy i wierzenia pogrzebowe oraz zaduszkowe mieszkańców regionu opoczyńskiego i radomskiego [Death as Eschatic Event. Tanatological Customs, Rites, and Beliefs of Opoczno and Radom Regions (in Poland) Citizens] (Lublin, 2007).

${ }^{16}$ Leksykon Teologii Fundamentalnej [Lexicon of Fundamental Theology], ed. Marian Rusecki, Krzysztof Kaucha, Ireneusz S. Ledwoń, Jacenty Mastej (Lublin-Kraków: Wydawnictwo M, 2002) (ss. 1429).
} 
field of fundamental theology in the world, ${ }^{17}$ covering all fundamental theology issues (278 subject headwords, 166 persons and 163 so-called reference passwords written by 109 authors who are specialists in fundamental theology, biblical studies, dogmatics, Church history, philosophy, sociology, psychology, religious studies). It was created at the initiative of Rev. Rusecki. The editorial team, along with the then Rector of the Catholic University of Lublin, Rev. A. Szostek, Rev. Z. Krzyszowski and representatives of M Publishing House on December 6, 2002, handed Pope John Paul II a specially issued copy during a private audience in the Vatican, to whom the lexicon was dedicated. For its preparation, the editors received the Lublin Scientific Award in 2002 (Premium Scientiarum Lublinense), called the Lublin Nobel.

The following textbooks were created at the school: Edward Kopeć, Teologia fundamentalna [Fundamental Theology] (Lublin: RW KUL, 1976, the first university textbook on fundamental theology in Poland); Stanisław Nagy, Chrystus w Kościele. Zarys eklezjologii fundamentalnej [Christ in the Church. An Outline of Fundamental Ecclesiology] (Wrocław: Publishing House of Wroclaw's Archdiocesan Bookstore, 1982, the first post-conciliar textbook on fundamental ecclesiology in Poland); Stanisław Nagy, Kościót na drogach jedności [The Church on the Ways of Unity] (Wrocław: Wydawnictwo Wrocławskiej Księgarni Archidiecezjalnej, 1985); Marian Rusecki, Wiarygodność chrześcijaństwa [Credibility of Christianity], vol. 1: Z teorii teologii fundamentalnej [From Theory of Fundamental Theology] (Lublin: TN KUL, 1994, the only textbook on the methodology of fundamental theology so far) $;^{18}$ Religioznawstwo $w$ katechezie. Materiaty katechetyczne $z$ religioznawstwa [Religious studies in catechesis. Catechetical materials from religious studies], ed. Mieczysław Majewski and Henryk Zimoń (Kraków, 1987); Być chrześcijaninem dziś. Teologia dla szkót średnich [Be a Christian today. Theology for high school], ed. by Marian Rusecki (Lublin: RW KUL, 1992); Religia w świecie wspótczesnym. Zarys problematyki religiologicznej [Religion in the modern world. An outline of religiological issues], ed. by Henryk Zimoń (Lublin: TN KUL, 2000).

\footnotetext{
${ }^{17}$ Enciclopedia di Teologia Fondamentale [Encyclopedia of Fundamental Theology], vol. 1, ed. Giuseppe Ruggieri (Genova: Marietti, 1987); Dizionario di Teologia Fondamentale [Dictionary of Fundamental Theology], ed. René Latourelle, Rino Fisichella (Assisi: Cittadella, 1990). In addition to these Catholic studies, there was also a publication representing the Anglican tradition: Norman L. Geilser, The Baker Encyclopedia of Christian Apologetics (Grand Rapids, Mich.: Baker Books, 1999).

${ }^{18}$ See: footnote 4.
} 
Rev. Rusecki published several treatises that were the author's scientific monographs: Traktat o cudzie [Treatise on Miracles] (Lublin: Komitet Nauk Teologicznych PAN, Wydawnictwo KUL, 2006); Traktat o religii [Treatise on Religion] (Warszawa: Verbinum, 2007); Traktat o Objawieniu [Treatise on Revelation] (Kraków: Wydawnictwo Księży Sercanów, 2007); Traktat o wiarygodności chrześcijaństwa. Dlaczego wierzyć Chrystusowi? [Treatise on the credibility of Christianity. Why believe Christ?] (Lublin: TN KUL, 2010). He also published a monograph on the resurrection: Pan zmartwychwstat $i$ żyje. Zarys teologii rezurekcyjnej [The Lord is resurrected and alive. An outline of resurrection theology] (Warszawa: IW PAX, 2006). After his death, Traktat o Kościele [Treatise on the Church] was published, edited by Krzysztof Kaucha, Piotr Królikowski, and Jacenty Mastej (Lublin: Wydawnictwo KUL, 2015), in which his most important ecclesiological texts were collected.

Fundamental theologians from the Catholic University of Lublin published many collective scientific works, including the multilingual work Chrześcijaństwo jutra. Materiaty II Międzynarodowego Kongresu Teologii Fundamentalnej [Christianity tomorrow. Materials from the II International Congress of Fundamental Theology]. Lublin. September 18-21, 2001, eds. Marian Rusecki, Krzysztof Kaucha, Zbigniew Krzyszowski, Ireneusz S. Ledwoń, Jacenty Mastej (Lublin: TN KUL, 2001), and the so-called festschrifts devoted to the scientific achievements of their masters: Rev. Kopeć (Roczniki Teologiczno-Kanoniczne 32, no 2 (1985)), Rev. Nagy (Roczniki Teologiczne 43, no 2 (1996)), Rev. Rusecki (Scio Cui credidi. Księga pamiatkowa ku czci Księdza Profesora Mariana Ruseckiego w 65. rocznice urodzin) [A memorial book in honor of Professor Marian Rusecki on his 65th birthday], ed. Ireneusz S. Ledwoń, Krzysztof Kaucha, Zbigniew Krzyszowski, Jacenty Mastej, Andrzej Pietrzak (Lublin: Wydawnictwo KUL, 2007); Roczniki Teologii Fundamentalnej $i$ Religiologii [Annals of Fundamental Theology and Religiology] 5(60), no 9, (2013)) and Rev. Zimoń, Pluralizm kulturowy i religijny wspótczesnego świata. Księga pamiątkowa dedykowana Księdzu Profesorowi Henrykowi Zimoniowi SVD w 70. rocznice urodzin [Cultural and religious pluralism of the contemporary world. Commemorative book dedicated to Rev. Professor Henryk Zimoni SVD on his $70^{\text {th }}$ birthday], ed. Zdzisław Kupisiński, Stanisław Grodź (Lublin: Wydawnictwo KUL, 2010). The Institute has created a series of publications: Studia Religiologiczne [Religiology Studies] edited by Rev. Zimoń and Biblioteka Teologii Religii the "Library of Theology of Religion" by Fr. Ledwoń. Institute for Fundamental 
Theology edits the Roczniki Teologiczne no 9 (Fundamental Theology and Religiology).

\subsection{ORGANIZATIONAL ACHIEVEMENTS}

The most important achievement was "Christianity Tomorrow," the II International Congress of Fundamental Theology organized at the initiative of Rev. Rusecki at KUL on September 18-21, 2001 with the participation of scholars from Poland, the Czech Republic, Italy, Germany, Austria, the Netherlands, Spain, Switzerland, France, Belgium and the USA. For the first time, Poland hosted so many recognized theologians from abroad who could get to know Poland and the Catholic University of Lublin as a center of Catholic thought.

Other international scientific conferences in chronological order are: "The Church Today" session (May 16, 2003); the symposium "Europe, be yourself! European Forum in Lublin. The role and tasks of the Church in uniting Europe" (May 17-19, 2004, to commemorate the $84^{\text {th }}$ birthday of John Paul II, co-organizers: the Institute of John Paul II at KUL, the Committee of Theological Sciences PAN, the Lublin Scientific Society, patronage: by the Polish Committee for UNESCO); the conference "Christian Identity. Experiences of the Netherlands and Poland" (October 7-8, 2010, in cooperation with the Dominican Center for Studies on Theology and Society in Nijmegen and the Department of Dutch Literature and Language at KUL); the "Papal primacy at the service of the Church's unity" conference (November 18, 2014); the conference "Shifting Locations-Reshaping Methods. How New Fields of Research in Intercultural Theology and Interreligious Studies Elicit Methodological Extensions" (April 15-18, 2015; in cooperation with the European Society for Intercultural Theology and Interreligious Studies) and the conference "Faces of the Church in Poland. The $1050^{\text {th }}$ Anniversary of our Baptism" (April 5, 2016, under the patronage of the Committee of Theological Sciences of the Polish Academy of Sciences and the Association of Fundamental Theologians in Poland).

The most important national conferences include: the symposium "The Church's credibility in the face of changes in Poland. Quo vadis Ecclesia Polonorum?" (April 8-9, 1991); the session "Christianity and Religions" (April 30, 1998); the symposium "Concerning the Dominus Iesus declaration" (November 15, 2000); the symposium, "Guarding the identity of 
Christianity. Promotion of the Lexicon of Fundamental Theology" (October 24, 2002); the symposium "The Church in the times of John Paul II" (November 29, 2005); The Third Congress of the Association of Fundamental Theologists in Poland, "Polish personalism" (September 27-28, 2007); the symposium "Fifty-years revival of the Department of History and Ethnology of Religions" (October 24, 2008); the conference "Science towards paranormal phenomena" (April 28, 2009, dedicated to the Rev. Kopeć on the $10^{\text {th }}$ anniversary of his death); the conference "Religious studies in Poland" (October 25, 2010); the conference "The need for Religion. The dynamics of religious and ritual practices" (March 10-11, 2014) and the conference "Christianity in folk religiosity. 1050 years after the Baptism of Poland" (May 910, 2016).

Every year since 2013, the Institute organizes the "Marian Rusecki Memorial Lectures" to commemorate Rev. Rusecki. There were 5 editions. The first was a nationwide conference "What can Christianity bring in the era of smartphones?" (December 2, 2013, organized by PhD students). The second edition (December 17-18, 2014) was devoted to the issue of papal primacy and consisted of two parts: guest lectures lead by Rev. Prof. Wolfgang Klausnitzer "Papal Primacy" (November 17, 2014) and the international and ecumenical conference "Papal primacy at the service of the Church's unity" (November 18, 2014, coorganized by the Ecumenical Institute of the Catholic University of Lublin, Committee for Theological Sciences of the Polish Academy of Sciences, Theology Committee of the Polish Academy of Sciences in Lublin and the Lublin Scientific Society VI Department of Theological Sciences).

The third edition was a two-day national scientific conference "Theology and natural sciences" with guest lectures by Rev. Wojciech Grygiel from UPJPII in Kraków, the Interdisciplinary Research Center and the Copernicus Center (Nov 30-Dec 1, 2015). The fourth edition was a two-day national conference "Fundamental Theology in the Work of Joseph Ratzinger" (December 12-13, 2016). The fifth was a two-day nationwide conference "100 years of Fundamental Theology at KUL" (December 3-4, 2017).

In January 2004 and 2005, the Institute organized the celebration of Islamic Days in the Catholic Church in Poland in cooperation with the Muslim community in Lublin. 


\subsection{NATIONAL AND INTERNATIONAL COOPERATION}

Fundamental theologians at the Catholic University of Lublin were actively involved in the work of the National Section of Lecturers of Fundamental Theology at the Episcopal Commission for Catholic Doctrine, and were also its chairmen (Rev. Kopeć, Rev. Nagy, Rev. Rusecki). In 2005, on the initiative of Rev. Rusecki, it evolved into the Association of Fundamental Theologians in Poland having a legal personality facilitating close cooperation among all centers of fundamental theology in Poland. The first chairman was Rev. Rusecki, who served this function until his death.

Rev. Rusecki also led to including theology within the group of scientific disciplines associated in the Polish Academy of Sciences (PAN), and in 2003, he established the Committee of Theological Disciplines of the Polish Academy of Sciences, where he was the chairman until 2011 and the editorin-chief of "Studia Nauk Teologicznych PAN" and the publishing series, "Christianity's Contribution to Culture." He led to the creation of the VI Committee of Theological Disciplines in the Lublin Scientific Society (which he headed: currently, the vice-chairman is Rev. Mastej) and the Theology Committee in the Lublin branch of the Polish Academy of Sciences (whose chairman is Rev. Kaucha).

Fundamental theologians from the KUL belong, apart from the abovementioned, to other national scientific organizations, among others the Polish Theological Society, the Polish Society of Ethnology, the Polish Association of Religious Studies, the Association of Polish Misiologists, the Polish Association of Latin American Studies, the Copernicus Center for Interdisciplinary Studies in Kraków and the Polish Society of Logic and Philosophy of Science...

Employees of the Institute of Fundamental Theology at KUL cooperated and continue to cooperate with foreign academic research organizations. Rev. Nagy was a member of the International Theological Commission. In 2003, John Paul II granted him the dignity of cardinal, a distinction given not only for his achievements, but also for the Catholic University of Lublin and the Lublin School of Fundamental Theology. Along with the nomination of John Paul II, Rev. Rusecki became a member of the Pontifical Academy of Theology in the Vatican. He was a consultant of the Scientific Council of the Polish Episcopate Conference. As the only foreign speaker, he was invited to a conference for dogmatists and fundamental theologians from German speaking countries, "Das Proprium der Fundamentaltheologie" (Paderborn, 
May 22-24, 2009). Several employees of the Institute belong to the European Society for Catholic Theology. Rev. Kupisiński is a member of the International Anthropos Institute and the Polish section of the International Organization of Folk Art. Rev. Pietrzak belongs to Asociación de Historiadores Latinoamericanistas Europeos.

Due to the joint scientific ventures of the entire Institute or individual employees, the Institute of Fundamental Theology cooperated with the following foreign academic and Church centers: the Pontifical Council for Culture, the Pontifical Council for Promoting New Evangelization, the Pontifical Gregorian University in Rome, the Pontifical Lateran University of Rome, Pontifícia Universidade Católica de Minas Geraisa (Brazil), the European Society for Intercultural Theology and Interreligious Studies (ESITIS), Anthropos Institute in Sankt Augustin (Germany), the University of Miskolc (Hungary), the University of Julius-Maximillians in Würzburg (Germany), the Dominican Center for Studies on Theology and Society in Nijmegen (Holland), the University of Vytautas the Great in Kaunas (Lithuania), the Faculty of Orthodox Theology at the University of Oradea (Romania), Universidade Lusófona in Lisbon (Portugal), and the Major Seminary in Grodno (Belarus) and Lviv (Ukraine).

Writing these words, it is difficult to remain objective towards the Lublin School of Fundamental Theology, its achievements and significance. However, it will be objective to say that this school was shaped as a pioneering center for post-conciliar fundamental theology in Poland, which has fulfilled its most important task, and other centers joined us over time. The establishment of this school was conditioned by the needs of the moment, and all this was possible thanks to outstanding academic scholars shaping it, mainly Rev. Rusecki, who consciously sought to create a school. The entire university was its "mother" and also had a significant influence on it. The creators of the school, after defining its methodological foundations, used the achievements of the employees of the Faculty of Theology of the Catholic University of Lublin, especially Rev. Czesław S. Bartnik's Lublin School of Personalism, as well as the achievements of the Lublin School of Classical Philosophy, especially the works of M.A. Krąpiec, Z.J. Zdybicka, S. Kamiński, K. Wojtyła, T. Styczeń, S. Wielgus and A. Bronk. 
Today, it is difficult to say what the future of this relatively young school will be, whether it will survive and in what condition. It is still young, because if it dates back to Rev. Kopeć, its second generation has now obtained scholastic maturity, and if we date back to Rev. Rusecki, it's only the first generation. A lot depends on the scholars currently working in it. Very recently two of them (Rev. Mastej and Rev. Kaucha) as Rev. Rusecki closest disciples $^{19}$ relased a new book on methodology of fundamental theology. This book reminds Rev. Rusecki's achievements on that field and also updates them.

\section{BIBLIOGRAPHY}

Badania nad religiami Afryki oraz religijnościa ludowa Polski i Ukrainy [Researches of African Religions and of Folk Religion in Poland and Ukraine], edited by Henryk Zimoń, Zdzisław Kupisiński, Stanisław Grodź. Lublin: TN KUL, 2009.

Badania religiologiczne w Polsce [Religiology Researches in Poland], ed. Zdzisław Kupisiński. Lublin: Wydawnictwo KUL, 2011.

HŁadowski, Władysław. "Polski Leksykon Teologii Fundamentalnej” [Polish Lexicon of Fundamental Theology]. Collectanea Theologica 73, no 2 (2003): 171-174.

Kaucha, Krzysztof. "Doctor Credibilitatis. Śp. Rev. prof. dr hab. dr hc Marian Jan Rusecki (22 III 1942-15 XII 2012)" [Doctor of Credibility. R.I.P. Rev. prof. dr hab. dr hc Marian Jan Rusecki (22 III 1942-15 XII 2012)]. Roczniki Teologii Fundamentalnej i Religiologii 5(60) (2013): 5-12.

KaUcha, Krzysztof. "Pokłosie II Międzynarodowego Kongresu Teologii Fundamentalnej 'Chrześcijaństwo jutra' (KUL, 18-21 września 2001). Omówienie korespondencji, sprawozdań i recenzji” [Fruits of the Second International Congress of Fundamental Theology „Christianity of Tomorrow” (Catholic University of Lublin, September 18-21, 2001). Discussing Correspondence, Reports, and Reviews]. Roczniki Teologiczne 50, no 9 (2003): 155-161.

KAUCHA, Krzysztof. "Wiarygodność i wiara w ujęciu lubelskiej szkoły teologii fundamentalnej” [Credibility and Faith according to Lublin School of Fundamental Theology]. In Wiarawiarygodność [Faith—Credibility], edited by Damian Wąsek, 49-85. Kraków: Wydawnictwo Naukowe UPJPII w Krakowie, 2014.

KĘDZIERSKI, Jacek. "Chrześcijaństwo jutra. II Międzynarodowy Kongres Teologii Fundamentalnej" [Christianity of Tomorrow. The Second International Congress of Fundamental Theology]. Ateneum Kapłańskie 138 (2002), 3(559): 594-599.

ŁUKASZYK, Romuald. "Pięćdziesięciolecie teologii fundamentalnej na KUL (1919-1968)" [Fifty Years of Fundamental Theology at Catholic University of Lublin (1919-1968)]. Roczniki Teologiczno-Kanoniczne 15, no 2 (1968): 5-53.

\footnotetext{
${ }^{19}$ Marian RuSECKI, Jacenty MASteJ, Krzysztof KAUChA, Metodologia teologii fundamentalnej [Methodology of Fundamental Theology], ed. Jacenty Mastej, Krzysztof Kaucha (Lublin: TN KUL, 2019).
} 
NAGY, Stanisław. "Sekcja Teologii Fundamentalnej" [Section of Fundamental Theology]. In Księga pamiątkowa w 75-lecie Katolickiego Uniwersytetu Lubelskiego. Wkład w kulturę polska w latach 1968-1993 [75 Years of Catholic University of Lublin Jubilee Book. Contribution to Polish Culture in the Period of 1968-1993], edited by Marian Rusecki, 188-197. Lublin: RW KUL, 1994.

Pluralizm kulturowy i religijny wspótczesnego świata. Księga pamiątkowa dedykowana Księdzu Profesorowi Henrykowi Zimoniowi SVD w 70. rocznice urodzin [Cultural and Religious Pluralism of Contemporary World. Festschrift Dedicated to Rev. Professor Henryk Zimoń in Occasion of His 70th Birthday], edited by Zdzisław Kupisiński, Stanisław Grodź. Lublin: Wydawnictwo KUL, 2010.

RUSECKI, Marian. "Elementy personalistycznej teologii fundamentalnej w ujęciu Edwarda Kopcia" [Elements of Personalistic Fundamental Theology according to Edward Kopeć]. Roczniki Teologiczno-Kanoniczne 32, no 2 (1985): 23-37.

Scio cui credidi. Księga pamiątkowa ku czci Księdza Profesora Mariana Ruseckiego w 65. rocznice urodzin [I know Whom I believed. Festschrift Dedicated to Honor Rev. Professor Marian Rusecki at His 65th Birthday], edited by Ireneusz S. Ledwoń, Krzysztof Kaucha, Zbigniew Krzyszowski, Jacenty Mastej, Andrzej Pietrzak. Lublin: Wydawnictwo KUL, 2007.

SEWERYNIAK, Henryk. "Profesor dr hab. Stanisław Nagy SCJ—teolog na służbie Kościoła" [Professor Dr Hab. Stanisław Nagy SCJ - Theologian in the Service of the Church]. Roczniki Teologiczne 43, no 2 (1996): 7-16.

SEWERYNIAK, Henryk. "W stronę personalistycznej teologii fundamentalnej" [In the Direction of Personalistic Fundamental Theology]. In Historia i Logos [History and Logos], edited by Kazimierz Macheta, Krzysztof Góźdź, Mirosław Kowalczyk, 285-296. Lublin: Wydawnictwo KUL, 1991.

SKIERKOWSKI, Marek. "Wiara i/a wiarygodność w ujęciu ośrodka warszawskiego" [Faith and Credibility according to Catholic academics in Warsaw]. In Wiara-wiarygodność [FaithCredibility], edited by Damian Wąsek, 87-102. Kraków: Wydawnictwo Naukowe UPJPII w Krakowie, 2014.

ZIMOŃ, Henryk. "W trzydziestolecie reaktywowania Katedry Historii i Etnologii Religii Katolickiego Uniwersytetu Lubelskiego" [In Occasion of the 30th Anniversary of Reactivation of the Chair of History and Ethnology of Religion at Catholic University of Lublin]. In Z badan nad religia i religijnościa ludowa [Out of Researches of Religion and Folk Religion], edited by Henryk Zimoń, 149-158. Warszawa: Verbinum, 1988.

\section{Translated by Jan Kobytecki}

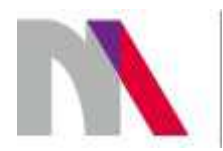

The preparation of the English version of Roczniki Teologiczne (Annals of Theology) and its publication in electronic databases was financed under contract no. 836/P-DUN/2018 from the resources of the Minister of Science and Higher Education for the popularization of science. 